nie było w poprzednim wydaniu tego słownika. Są to między innymi takie hasła jak: Aniołowie, Błogosławieństwo, Kalendarz liturgiczny, Katechizm Kościoła Katolickiego, Katechumenat, Komunikacja i liturgia, Kongregacja Kultu Bożego i Dyscypliny Sakramentów, Kult Eucharystyczny poza Msza Świetą, Diakonat, Bóg, Ojciec, Hermeneutyka, Lekcjonarz, Egzorcyzmy, Niepełnosprawni i liturgia, Grupa liturgiczna, Świeccy, Lekcjonarz, Martyrologium, Mistagogia, Ruch liturgiczny we Włoszech, Odnowa liturgiczna, Ryt hebrajski, Czasopisma liturgiczne, Życie konsekrowane i liturgia.

Słownik ten z pewnością będzie użyteczny nie tylko profesorom liturgiki, seminarzystom, studentom teologii i innych specjalizacji, siostrom zakonnym, ale także wszystkim wiernym, którzy pragną pogłębiać swoją wiedzę na temat liturgii, by w ten sposób móc ją przeżywać świadomie, czynnie i owocnie. Dzieło to może stanowić wspaniałą pomoc wszystkim animatorom życia liturgicznego, katechetom instytutom świeckim, studentom kolegiów teologicznych, dziennikarzom, wszystkim twórcom kultury i wszystkim chrześcijanom.

Drohiczyn

KS. TADEUSZ SYCZEWSKI

\title{
S. PINTOR, La formazione permanente del clero, orientamenti e percorsi, Bolonia 2001, ss. 142.
}

W pierwszej połowie 2001 roku ukazała się we Włoszech książka pt. Formacja stała kapłanów, kierunki $i$ wskazania, w wydawnictwie: Edizioni Dehoniane Bologna. Autorem tej pozycji jest ksiądz Sergio Pintor, pochodzący $\mathrm{z}$ archidiecezji Oristano we Włoszech. Jest on profesorem teologii pastoralnej na Wydziale Teologicznym na Sardenii w Cagliari. Wykłada także na Uniwerytecie Urbanianum w Rzymie. Organizuje on liczne kursy i spotkania na temat formacji pastoralnej nie tylko kapłanów, ale także i katolików świeckich. Opublikował liczne książki z dziedziny teologii pastoralnej. Współpracuje także z czasopismami specjalistycznymi.

W książce Formacja stała kapłanów autor podkreśla, iż odnowa pastoralna zależy przede wszystkim od formacji stałej samych kapłanów. Formacja ta dotyczy każdego prezbitera, wszystkich odpowiedzialnych za organizacje życia duszpasterskiego, jak również od kościołów lokalnych. 
Wszelkie sugestie zawarte w tej książce mają służyć poszczególnym kapłanom w ich pracy duszpasterskiej i mogą być wykorzystane w każdej diecezji, prowadzącej formację stałą kleru. Pozycja ta przedstawia w sposób syntetyczny i organiczny konkretne wskazania odnośnie do formacji stałej kapłanów na najbliższe lata.

Autor w tej książce podkreśla, iż problem formacji stałej kapłanów nie jest czymś nowym w Kościele. Aktualne problemy wypływają z warunków społeczno - kulturalnych, kościelnych i pastoralnych.

Pozycja ta zawiera siedem rozdziałów. W pierwszym przedstawia konkretne dokumenty Kościoła Powszechnego, jak również Episkopatu włoskiego mówiące o potrzebie odnowy formacji stałej kapłanów. Jeśli chodzi o wskazania Kościoła Powszechnego, to są to następujące dokumenty poruszające ten problem: Sobór Watykański II, Dekret Christus Dominus, Optatam Totius, Presbyterorum Ordinis; Instrukcja o formacji stałej kleru z 4.11.1969; Synod z 1990 roku; Jan Paweł II, Pastores dabo Vobis z 25 III 1992 roku; Dyrektorium dla posługi i życia prezbiterów z 1994 roku.

Jeśli zaś chodzi o dokumenty episkopatu włoskiego poruszające to zagadnienie, są to następujące pozycje: Przygotowanie do kapłaństwa ministerialnego z 15.08.1972; Dokument na temat seminarium i powołania kapłańskiego z 16.10.1979; Formacja prezbiterów w Kościele włoskim. Orientacje i normy z 15.05.1980; Dokument Komisji biskupów do spraw duchowieństwa. Formacja stała prezbiterów. List do kapłanów z 18.05.2000.

W drugim rozdziale tej książki mówi się na temat motywacji i trudności w celu aktualizacji formacji stałej kapłanów. Autor przypomina w tym rozdziale o tym, iż formację stałą kapłanów można rozpatrywać na trzech płaszczyznach wzajemnie od siebie zależnych: ludzkiej, społeczno-kulturalnej i teologiczno-pastoralnej.

Jeśli chodzi o trudności związane $\mathrm{z}$ formacją stałą kapłanów to rozważa on je na płaszczyźnie warunków społeczno-kościelnych i strukturalnych, następnie na płaszczyźnie personalnej jako kapłanów.

Rozdział trzeci tej pozycji porusza zagadnienie tożsamości i zasadniczych celów formacji stałej kapłanów. Akcentuje się tutaj między innymi potrzebę pomocy prezbiterom w pogłębieniu ich wiedzy na temat kapłana jako człowieka tajemnicy oraz to w jaki sposób winien on postępować w różnych sytuacjach. Należy pomagać kapła- 
nom w pogłębianiu ich tożsamości. Podkreśla się także problem kapłan jako człowieka wspólnoty, wreszcie pomoc kapłanom we wzrastaniu i dojrzewaniu w świadomości - kapłan jako człowiek misji posłania.

Rozdział czwarty podkreśla zakres i cel formacji stałej kapłanów. Jest tutaj mowa o formacji ludzkiej, duchowej, intelektualnej, pastoralnej i o różnych kryteriach takiej formacji, czyli o miłosierdziu, tajemnicy, komunii, misji.

W rozdziale piątym tej książki jest mowa o celach i kryteriach formacji stałej kapłanów. Poruszony został tutaj problem pewnego rozwoju i dojrzewania w wierze, we wzrastaniu we wspólnocie i duchowości kapłańskiej, zdolności do służby braciom, wzrastaniu w świadomości własnego uczestnictwa w misji zbawczej Kościoła i w głębszej świadomości duchowości misyjnej. Jest poruszone bardzo obszernie zagadnienie wiary w służbie duszpasterskiej w ramach formacji stałej. Autor przedstawia tutaj także kryteria metodologiczne formacji stałej kleru.

Rozdział szósty zawiera treści i kierunki w aktualizacji formacji stałej kapłanów. Między innymi zajmuje się dojrzałością ludzką, dojrzałością wiary i duchowości, pogłębieniem biblijno - teologicznym i pastoralnym. Jest tutaj także mowa o etapach formacji stałej kapłanów. W pierwszym etapie należałoby pogłębić swoje powołanie na płaszczyźnie teologicznej, duchowej, kościelnej pastoralnej. W kolejnych etapach winno się podkreślać wzajemną zależność różnych wymiarów: ludzkiego, duchowego, intelektualnego, pastoralnego, następnie różnych środowisk służby kapłańskiej w głoszeniu Słowa Bożego. Ważne są tutaj spotkania kapłanów mające na celu pogłębienie własnej duchowości kapłańskiej i fachowej wiedzy teologicznej. Mowa jest tutaj także o odpowiedzialnych za formację stałą kapłanów i miejscach takiej formacji. Odpowiedzialnym za formację jest najpierw sam kapłan, wspólnota kapłańska w łączności z biskupem, biskup, a także katolicy świeccy. Jeśli zaś chodzi o miejsca, w których winna się odbywać formacja stała kleru, to najpierw jest nim życie duszpasterskie prezbiterów, czyli celebracja sakramentów świętych, modlitwa osobista kapłana, modlitwa wspólnotowa kapłanów - Liturgia Godzin, kierownictwo duchowe wiernych, służba miłości, poradnictwo duszpasterskie. Następnie takimi miejscami są: wspólnota kapłańska, czy to w wymiarze diecezjalnym, czy nawet 
szerszym np. metropolii. Ważne miejsce w takiej formacji zajmuje studium, ciągłe dokształcanie w dziedzinie teologicznej.

W rozdziale siódmym tej książki jest mowa o formacji stałej, której zadaniem jest odnowa pastoralna. Kapłani mają za zadanie zastanawiać się nad tym, jaka działalność duszpasterska przyniesie godne owoce w najbliższych latach życia Kościoła. Należałoby przede wszystkim zwrócić uwagę na głoszenie Słowa Bożego i Jego akceptacji w życiu. Postawić w centrum życia duszpasterskiego Tajemnicę Paschalną celebrowaną w liturgii, pogłębić świadomość Kościoła u katolików świeckich jako Ludu Bożego, uwrażliwiać na sprawy misyjne Kościoła. W posłudze duszpasterskiej ważna jest postawa bezinteresowności, autentyczności wewnętrznej głębi i dojrzałości, wreszcie postawa miłości (por. 1 Kor 13, 1).

Poruszone jest tutaj zagadnienie niektórych kryteriów i zasadniczych akcentów, które mogą przyczyniać się do pogłębienia działalności pasterskiej w nabliższych latach. Jest to kryterium istotności, kryterium braterskiej wspólnoty, kryterium pedagogiczno-edukacyjno-formujące, kryterium komunikacji i kryterium miłości i misji.

Formacja stała kapłanów wydaje się czymś koniecznym we współczesnym świecie. Przyczynia się do wzrostu ludzkiego kapłana, do jego autentyzmu, świadectwa, a to wszystko ma na celu odnowę Kościoła i jego działalności pastoralnej. Formacja prezbiterów musi mieć zatem konkretne odniesienie do procesu nawrócenia. Podstawą takiej formacji nie jest przede wszystkim bogactwo strukturalne, liczne inicjatywy, wielkie programy. U podstaw takiej formacji ma być postawa teologalna: wiara, nadzieja i miłość. Ta postawa ma się wyrażać przede wszystkim w pokorze, odpowiedzialności, nawróceniu, zaufaniu, solidarności, służbie jedni drugim, w cierpliwości, w naśladowaniu Chrystusa.

Drohiczyn

KS. TADEUSZ SYCZEWSKI 